\title{
Physicochemical and Fatty Acid Profile of Fish Oil from Head of Tuna (Thunnus albacares) Extracted from Various Extraction Method
}

\author{
Novizar Nazir", Ayu Diana*, Kesuma Sayuti ${ }^{*}$ \\ ${ }^{\#}$ Faculty of Agricultural Technology, Andalas University, Padang, Indonesia \\ E-mail: nazir_novizar@yahoo.com \\ State Polytechnic of Tanjung Balai, North Sumatra. Indonesia
}

\begin{abstract}
By-product of tuna fish processing industry has the potential to be developed into fish oil rich in omega. Fish by-products are the main natural source of omega-3 polyunsaturated fatty acids, EPA (eicosapentaenoic acid) and DHA (docosahexaenoic acid) with a great importance in food industry and pharmacy. The purpose of this research is to see the effect of fish oil extracting method from the head of tuna fish as by-product of tuna fish processing industry to the physicochemical properties and the profile of fatty acid fish oil. There are several methods of extraction to produce of fish oil. This research was run in triplicate with a completely randomized design (CRD) with three treatments: pre-cooked wet rendering, acid silage, and solvent extraction. It can be concluded that the extraction method has an effect on physicochemical properties and fatty acid profile of fish oil. The wet rendering extraction method is the most effective and most potential extraction method to be applied because it produces the highest yield (12.80\%) compared to the silage process $(6.16 \%)$ and solvent extraction method $(8.49 \%)$. PUFA produced from wet rendering was $44.34 \%$, statistically not different with solvent extraction method (44.49\%), but it higher than silage process method (32.77\%).
\end{abstract}

Keywords - fish oil extraction; tuna (Thunnus albacares); wet rendering; silage process; solvent extraction; poly unsaturated fatty acid (PUFA); EPA; DHA

\section{INTRODUCTION}

It is estimated that more than $70 \%$ of the total processing of processed fish fishery produces large amounts of solid waste and by-products. Fish fillet industry can produce waste that sometimes reaches $50 \%$ of the total weight of processed fish [1]. Most by-products from fish processing are further processed into fish flour for feed. However, the by-products of processing products still have the potential to be developed into more economically valuable products, one of which is fish oil.

Junker et al. [2] said that the fish waste obtained from the processing industry is still very rich in omega fatty acids. The demand for fish oil products continues to increase, since it is known that fish oil is a good source of polyunsaturated fatty acids such as omega. Polyunsaturated long chain fatty acids Unsaturated fatty acids (PUFAs) are important substances for maintaining health and growing human development [3]. This oil is an important source of essential dietary components such as eicosapentaenoic acid and docosahexaenoic acid [4] Epidemiological and experimental facts has shown that n-3 polyunsaturated fatty acids (n-3 PUFA), especially eicosapentaenoic acid (EPA, 20:5 n-3) and docosahexaenoic acid (DHA, 22:6 n-3) are among the main components responsible for the health benefits resulting from fish consumption [5]

Fish oil from by-product of various fish sources has been extensively studied by many researchers, such as study on the quality of fish oil from precooked and non-precooked tuna heads [6], fish oil from by-products of herring fillet [7] salmonella skin [8], mackerel fish waste [9], By-products of trout [10] fish waste Cyprinus carpio [11] and catfish waste [12]. There are several kinds of fish oil extraction methods. Extraction methods that are usually used are wet rendering and dry rendering methods. Those methods do not require chemicals during process. Wet rendering extraction involves cooking of fish with steam to damage the structure of cell and pressing the oil from the cooked fish. This is the most common method used for fish oil production which involves three basic steps: cooking at high temperatures $\left(85-95{ }^{\circ} \mathrm{C}\right)$, pressing and centrifuging [13]. High volumes of crude fish oil could be obtained from this process. For edible purposes, subsequent refining steps are required. According to Ref.[14], the optimum temperature for wet rendering was $80{ }^{\circ} \mathrm{C}$.

Other processes, such as, the study for obtaining crude oil from fish by-products by enzymatic reaction with proteases 
[15]. Supercritical fluid extraction (SFE) method has become an attractive technology for obtaining high quality fish oil from some by-products $[16,17]$. It is not only because it uses moderate temperatures and provides an oxygen free media, which aim to reduce oxidation of omega-3 during the extraction, but also because it selectively allows extracting low polar lipid compounds, avoiding the co-extraction of polar impurities such as some inorganic derivatives with heavy metals. High production cost is the main limitation of the SFE process [17].

The other methods are the acid silage and the solvent extraction, both methods are the process of separating a substance from its mixture by dividing a solute between two non-mixed solvents to extract the solute from one solvent to another. Fish silage is defined as a liquid product obtained from the whole or parts of fish, where acids, enzymes or lactic-acid-producing bacteria are added. Liquefaction is then stimulated by the action of enzymes from the fish [18].

Solvent extraction is typically used to obtain components of a solid or liquid material. Solvent contact with samples which will dissolve the desired solute. The success of solvent extraction depends on how quickly the compound to be extracted is dissolved, and at equilibrium is achieved in the solvent phase. Solvent extraction is considered a process of mass transfer between solid phases (insoluble solid matrix), liquid phase is clogged in the pores within the article, and the miscella that travels through space between particles [19]

Selection of the extraction process to obtain omega- 3 rich oils is essential to get the best oil quality. This is because the method of extraction not only affects the oil extraction results, but also the quality of the oil [20]

The purpose of this research is to see the effect of fish oil extraction method on the physicochemical properties and fatty acid profile of fish oil from head of tuna (Thunnus albacares).

\section{MATERIALS AND MEthODS}

\section{A. Raw material and pre-treatment}

The raw materials studied in this study are by-products of yellow fin tuna (Thunnus albacares) processing which is still fresh in the form of head. Raw materials taken directly from the Tuna Fish Processing Industry in Bungus Padang, West Sumatra-Indonesia. Raw material came from a unique batch (related to a certain place, season of fish capture and processing batch), which was delivered frozen at $-2^{\circ} \mathrm{C}$. Each batch received in the laboratory was cut in small pieces (1$10 \mathrm{~mm}$ equivalent diameter) with a cutter, packed in individual plastic bags under vacuum and kept frozen until the experiments were performed.

\section{B. Oil extraction methods}

Oil from each fish by-product was obtained in parallel by three different methods: solvent extraction (SE) or centrifuging, wet rendering (WR), acid silage extraction (AS). The amount of raw material used in each extraction method was approximately $100 \mathrm{~g}$. The scheme of extraction procedure in this research can be seen in Figure 1.

The precooked-wet rendering extraction process are as follow: a) washing raw material of by-product of fish processing with running water, b) steaming at $105{ }^{\circ} \mathrm{C}$ for 30 minutes, c) pressing; (d) separating liquid and cake, e) liquid (oil and water) separated by separating funnel, f) centrifuging the oil in top layer $(10,000 \mathrm{rpm})$ for 10 minutes, g) crude fish oil was produced. Homogenized by-product was added with distilled water at a ratio of 1: 1. [21].

The acid silage extraction process are as follows: a) washing raw materials of by-product b) soaking with $3 \%$ formic acid, c) stand-by at room temperature for 4-7 days, d) separating the liquid and cake using by filtering, e) centrifuging at $10,000 \mathrm{rpm}$ for 10 minutes, f) pressing the cake to produce the oil-water mixture and centrifuging at $10,000 \mathrm{rpm}$ for 10 minutes. (g) collecting crude oil.

In a solvent extraction process, $5 \mathrm{~g}$ of solid sample was placed on a cotton-coated porous thimble. The solvent used is hexane with a boiling point of $60-80^{\circ} \mathrm{C}$. Hexane was used as a solvent. Thimble which already filled with samples was placed in soxhlet. Soxhlet was connected to a flask and placed on an electric heater and condenser. The cooler was connected with soxhlet. Heat was applied to heat the solvent to its boiling point for 1 hour. As the warming continues, the solvent in the flask begins to boil in just 5 minutes of warming and the water begins dropping from the top to the sample in the thimble. When the solvent reaches the top of the tube, it sucks into the flask and thereby removes the oil part that has been extracted in the reflux process. The solvent used is then recovered by applying heat and collected on top of a round bottom flask into the soxhlet apparatus while the extracted oil is collected and measured.

\section{Yield Determination}

Yield was expressed as a percentage of oil extracted from tuna heads. Yield was calculated as follows:

$$
\text { Yield }=\frac{\text { Extracted fish oil }}{\text { Weight of sample }} \times 100 \%
$$

\section{Oil Refining [22]}

1) Degumming: Degumming is a process of separation of gums consisting of phosphatides, proteins, residues, carbohydrates, water and resins without reducing fatty acids in oil. The oil is shaken or stirred first, weighed and heated to $70^{\circ} \mathrm{C}$. The oil is put into a separator flask. Add hot water as much as 10-20 percent oil volume and then stand for 10 minutes till the mixture form three layers of oil, gum, and water. Water and gum are removed from the separating flask. The $\mathrm{pH}$ check is performed by measuring the $\mathrm{pH}$ of the separated water. This separation of gums and water is carried out until the $\mathrm{pH}$ of water reaches neutral.

2) Neutralization: Degummed oil is weighed and heated to $80^{\circ} \mathrm{C}$. Add caustic soda according to the calculation and stirred with stirrer for 2 minutes. After that, the oil is put into the separator flask and then washed with hot distilled water as much as 5 percent of the weight of the oil. After forming three layers that consist of oil, soap stock and water, then soap and water are separated from oil. The separation is stopped until the $\mathrm{pH}$ of the separating water becomes neutral. Once the $\mathrm{pH}$ becomes neutral, add 1 percent of the 
anhydrous salt to the oil to reduce the water content of the oil.

3) Bleaching: The neutralized oil is weighed and heated to $80-100^{\circ} \mathrm{C}$. Then add the active charcoal as much as 1 percent of the oil weight and stirred for 10 minutes. After mixing well, the oil is filtered with filter paper.

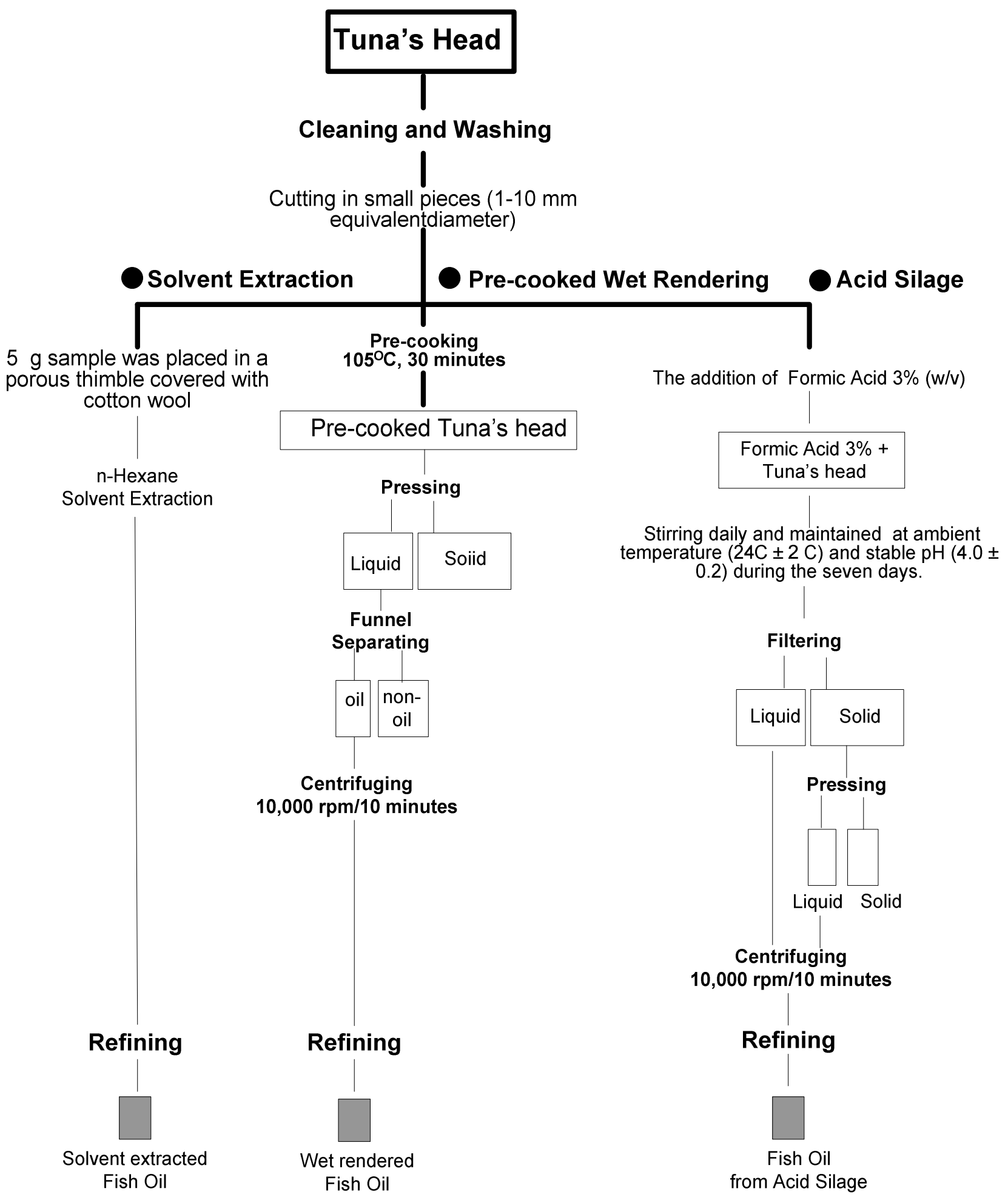

Fig 1. Scheme of the different fish oil extraction procedures studied in this work 


\section{E. Design Experiment}

The experiment was run in triplicate with a completely randomized design (CRD) with three treatments: precooked wet rendering, acid silage, and solvent extraction. The data were subjected to analysis of variance (ANOVA). The differences among the treatments were determined using Duncan's New multiple range test (DNMRT) [23].

\section{F. Physicochemical Properties of the tuna oils}

The free fatty acid content (FFA) and Acid number (AN). FFA and AN were determined according to AOCS Official method Ca 5a-40. 19. [24] A well mixed oil sample (7.05 \pm $0.05 \mathrm{~g}$ ) was accurately weighed into a $250 \mathrm{~mL}$ Erlenmeyer flask and $75 \mathrm{~mL}$ of hot neutralized $95 \%$ ethanol and $2 \mathrm{~mL}$ of $1 \%$ phenolphthalein indicator solution were added to the oil sample. The hot neutralized $95 \%$ ethanol was prepared by heating $75 \mathrm{~mL}$ of $95 \%$ ethanol with $2 \mathrm{~mL}$ of $1 \%$ phenolphthalein indicator solution to incipient boiling. The ethanol was neutralized by adding $0.25 \mathrm{~N}$ sodium hydroxide solution until a faint permanent pink colour appeared. The oil samples were then titrated against $0.25 \mathrm{~N}$ sodium hydroxide until the appearance of the first permanent pink colour of the same intensity as that of the neutralized ethanol before the addition of sample. The permanent pink colour persisted for at least 30 seconds during titration. The Free Fatty Acids content (\%FFA) and acid number were calculated using Equations:

$$
\text { FFA }(\%)=\frac{\mathrm{mL} \text { of alkali } \times \mathrm{N} \times 28.2}{\mathrm{w}}
$$

Where:

$\mathrm{N}=$ Normality of $\mathrm{NaOH}$ solution

$\mathrm{W}=$ Weight of oil $(\mathrm{g})$

$$
\text { Acid number }(\mathrm{mg} \mathrm{KOH} / \mathrm{g})=1.99 \mathrm{X} \mathrm{FFA}(\%)
$$

Saponification Value. $\boldsymbol{S} \boldsymbol{V}$ was determined according to AOCS Method cd 3-25 (1993) [25] A $0.002 \mathrm{~kg}$ of the oil sample was weighed into a volumetric flask. Then $25 \mathrm{~mL}$ of $1.0 \mathrm{~N}$ alcoholic $\mathrm{KOH}$ was pipetted and allowed to drain for about 1 minute into the mixture. A condenser was connected to the flask and the mixture sample allowed to boil gently but steadily for 45 minutes for complete saponification. The flask and the condenser were then cooled but not sufficiently to form a gel, the inside of the condenser was washed down with about $1 \mathrm{ml}$ of distilled water. The condenser was disconnected and $1 \mathrm{ml}$ of phenolphthalein indicator added. The solution was titrated with $0.5 \mathrm{~N}$ hydrochloric acid $(\mathrm{HCl})$ until the pink colour just disappeared. A blank determination was conducted simultaneously with the sample. The saponification value was calculated using the formula below:

$$
\text { Saponification Value }=\frac{56.1 \times \mathrm{N} \times(\mathrm{V} 2-\mathrm{V} 1)}{\mathrm{w}}
$$

Where,

$\mathrm{N}=$ normality of $\mathrm{HCl}$,
$\mathrm{V} 1=$ volume of $\mathrm{HCl}$ used in the test, $(\mathrm{mL})$

$\mathrm{V} 2=$ volume of $\mathrm{HCl}$ used in the blank, $(\mathrm{mL})$

$\mathrm{W}=$ weight of sample, $(\mathrm{g})$

Peroxide value $(\boldsymbol{P V})$. Measurement Peroxide value is a measure of peroxides contained in the oil. PV is determined by measuring iodine released from potassium iodide.The peroxide value was determined by AOCS official method Cd8-53. The test oil sample was filtered through a Whatman No. 40 filter paper to remove moisture and impurities. A $5 \mathrm{~g}$ sample of filtered oil was accurately weighed to $0.05 \mathrm{~g}$ in a $250 \mathrm{~mL}$ Erlenmeyer flask. $30 \mathrm{~mL}$ of $3: 2$ acetic acidchloroform was added and swirled to mix well. Two blank samples were simultaneously prepared without the addition of fish oil. To the samples, $0.5 \mathrm{~mL}$ of saturated potassium iodide solution was added and allowed to stand for exactly 1 min. Saturated potassium iodide solution was prepared by adding $10 \mathrm{~g}$ potassium iodide to $6 \mathrm{~mL}$ boiled distilled water so that undissolved potassium iodide crystals were present during analysis. After the standing time $30 \mathrm{~mL}$ of distilled water was immediately added to the oil samples and swirled to mix. The samples were titrated against $0.1 \mathrm{~N}$ sodium thiosulfate until the yellow iodine color disappeared. Starch indicator $(2 \mathrm{~mL})$ was added and the titration was continued against $0.1 \mathrm{~N}$ sodium thiosulfate until the blue color disappeared. The blank titration value must not exceed 0.1 $\mathrm{mL}$ and the peroxide value was calculated by using Equation $1[26]$.

\section{(S-B).N.1000}

mass of sample, $g$

Where:

$\mathrm{B}=$ volume of titrant, $\mathrm{mL}$. of blank

$\mathrm{S}=$ volume of titrant, $\mathrm{mL}$. of sample

$\mathrm{N}=$ normality of sodium thiosulfate solution

Iodine value (IV), Measurement A known weight of the oil sample is treated with an excess of iodobromine (IBr) in glacial acetic acid. Unreacted iodobromine is reacted with potassium iodide which converts it to iodine. The iodine concentration is then determined by titration with standard sodium thiosulphate.

$$
\mathrm{IV}=(\mathrm{b}-\mathrm{v}) \times \mathrm{N} \times 126.9 \times 100 / \mathrm{w} \times 1000 \text { (1) }
$$

Where $\mathrm{b}$ is the $\mathrm{mL}$ of sodium thiosulphate used for blank, $\mathrm{v}$ is the $\mathrm{mL}$ of thiosulphate for sample, $\mathrm{N}$ is the normality of thiosulphate solution, $w$ is the weight of oil sample and 126.9 is the molecular weight of iodine. [27]

Thio Barbituric Acid (TBA). Weigh $3 \mathrm{~g}$ of oil and put in flask and $50 \mathrm{~m}$ distilled water, then transferred into 1000 $\mathrm{ml}$ distillation flask while washed with $48.5 \mathrm{ml}$ distilled water and $1.5 \mathrm{ml} 4 \mathrm{~N} \mathrm{HCl}$. Add boiling stones and antifoam. The distillation is run as high as possible so as to obtain 50 $\mathrm{ml}$ of distillate during 10 minute heating. The destilate obtained was stirred, filtered and as much as $50 \mathrm{ml}$. Move it into a closed erlenmeyer and add $5 \mathrm{ml}$ of TBA reagents $(0.02$ $\mathrm{M}$ thiobarbituric-acid solution in $90 \%$ glacial acetic acid). 
The solution is mixed in a closed erlenmeyer and inserted into boiling water for 35 minutes. The reaction tube was cooled with running water and then measured its absorbance at $528 \mathrm{~nm}$ wavelength with blank solution as a zero boiling point. TBA number were calculated and expressed as $\mathrm{mg}$ of malonaldehyde / kg sample [28].

\section{G. Analysis of Fatty Acid Profile}

For determining the fatty acid profile, the tuna oils were subjected to methylation or derivatization, as described by Ref. [29]. The extracted oil is methylated into fatty acid methy ester (FAME) [30]. Put $1 \mathrm{~mL}$ of hexane into $0.1 \mathrm{~mL}$ of oil, and $1 \mathrm{~mL}$ of sodium methoxide solution $(1.55 \mathrm{~g}$ $\mathrm{NaOH}$ in $50 \mathrm{~mL}$ methanol) is added to the oil solution. The solution was stirred with a hard spin using a Vortex stirrer for 10 seconds. The solution is allowed for 10 minutes to separate the clear- coloured FAME solution from a cloudy aqueous layer. The top layer is carefully collected. The collected oil was measured using a UV-Vis DAD detector at a predetermined wavelength. The analysis was carried out using GC-MS Shimadzu QP 2010. A $1 \mu \mathrm{L}$ sample is injected into GC-MS operated using a 30-meter long glass column $\mathrm{M}$, $0.25 \mathrm{~mm}$ diameter and $0.25 \mu \mathrm{m}$ thickness with CP-Sil 5CB stationary phase with a pre-programmed oven temperature of $60-220^{\circ} \mathrm{C}$ with a temperature rise rate of $10^{\circ} \mathrm{C} / \mathrm{min}$. The carrier gas is $12 \mathrm{kPa}$ pressurized Helium with a total rate of $30 \mathrm{~mL} / \mathrm{min}$, and a split ratio of 1:50. From the chromatogram it can be determined the type and content of fatty acids belonging to saturated fatty acids (SFA), monounsaturated fatty acids (MUFA), and polyunsaturated fatty acids (PUFA).

\section{RESULT AND DISCUSSION}

\section{A. Effect of Extraction Method on Yields of Fish Oil}

Yields obtained after different treatments with different extraction method shown in Table 1. The silage extraction method was the lowest yield $(6.16 \%)$, followed by solvent extraction method $(8.48 \%)$. The highest yield was found in pre-cooked wet rendering extraction method. Cooking can coagulate the protein of fish, so that mechanically oil and solid materials from fish can be separated [6].

TABLE I

EFFECT OF EXTRACTION METHOD ON YIELD OF OILS

\begin{tabular}{|lc|}
\hline Extraction Method & Yield (\%) \\
\hline Wet rendering & $12.80^{\mathrm{c} \mathrm{a}}$ \\
Solvent extraction & $8.49^{\mathrm{b}}$ \\
Acid Silage & $6.16^{\mathrm{c}}$ \\
\hline
\end{tabular}

${ }^{a-c}$ Different superscripts indicate a significant difference at $P<0.05$ for DNMRT (Duncan's New Multiple Range Test)

Yields variation relates to whether the fish is cooked or not before it is extracted [6], how high the contact temperature during extraction [17] and whether there is contact with a particular solvent or not [8]. The wet rendering method is the best method for the extraction of fish oil in line with Rodriguez et al [17] because it involves three basic principles of extraction: cooking, pressing and centrifugation.
Different oil extraction results in this study were suspected because of differences in solvents (solvent and silage methods) and wet rendering methods that did not use solvents.

\section{B. Effect of Extraction Method on Chemical Properties of Oils}

Chemical Properties of Tuna Oils from Various Extraction Method is shown in Table 2.

Acid Value. Based on the data obtained from Table 2, the largest acid number was obtained on wet rendering method $(1.26 \%)$ and the silage method $(1.09 \%)$. The smallest acid value was obtained on solvent extraction method. Acidity of oil is an important quality parameter related to the presence of Free Fatty Acids (FFA) and other non-lipid acid compounds. FFA is primarily produced by the hydrolysis reaction of triacylglycerides, whereas non-lipid acid compounds, such as acetic acid, can be produced during the decay of the feedstock. Thus, the acidity of the oil depends on several factors relating to the oil composition, the extraction procedure and the freshness of the raw material [17].

The high number of acid numbers in the wet rendering method is suspected due to the hydrolysis process at the time of cooking the fish before it is extracted. Meanwhile, the silage method also produces a high acid number, presumably because the material is soaked in $3 \%$ formic acid solution which also causes hydrolysis of the material.

Free Fatty Acid. Carbon chains that have double bonds on unsaturated fatty acids will react with heat to form free fatty acids that can affect the quality of fish oil. The statement is in accordance with the opinion of unsaturated fatty acids will decompose due to the surface of the hot oil and direct contact with air, so that free fatty acids increase [34].

Free fatty acids are closely related to flavors that are less attractive to oil. In the fish oil processing industry the FFA value is closely related to the amount of alkali used in the purification process. Free fatty acids occur due to the hydrolysis process of triglycerides [6]. The Hydrolysis will occurs if oil in contact with water and heat [33].

Peroxide Value. Peroxide rate is the most important value to determine the degree of oil damage. Unsaturated fatty acids can bind oxygen to their double bonds to form peroxides, while saturated fatty acids can not react with oxygen to form peroxides because the bonds are saturated. The smaller the peroxide number means the better the quality of the oil. Oil damage can occur due to the oxidation process by oxygen from the air to unsaturated fatty acids in the oils that occur during processing or storage. Peroxide value (PV) determines the extent to which the oil has undergone rancidity during storage and it can be used to monitor the fats and oils quality and stability [35]. Precooked wet-rendered oils and oils derived from acid silage extraction process have higher PV than oil derived from solvent extraction process (Table 2). 
TABLE II

PHYSICOCHEMICAL PROPERTIES OF TUNA OILS FROM VARIOUS EXTRACTION METHOD

\begin{tabular}{|lcccccc|}
\hline \multirow{2}{*}{ Methods } & \multicolumn{5}{c|}{ Physicochemical Properties } \\
\cline { 2 - 7 } & Acid Value & FFA & Peroxide Value & Saponification Value & Iodine value & TBA \\
\hline $\begin{array}{l}\text { Wet } \\
\text { rendering }\end{array}$ & $1.05^{\mathrm{b}}$ & $0.55^{\mathrm{a}}$ & $2.93^{\mathrm{b}}$ & $126.46^{\mathrm{a}}$ & $109.10^{\mathrm{a}}$ & $0.79^{\mathrm{a}}$ \\
$\begin{array}{l}\text { Acid Silage } \\
\text { Solvent }\end{array}$ & $1.09^{\mathrm{b}}$ & $0.58^{\mathrm{a}}$ & $2.96^{\mathrm{b}}$ & $121.26^{\mathrm{b}}$ & $110.25^{\mathrm{a}}$ & $0.86^{\mathrm{b}}$ \\
Extraction & $0.88^{\mathrm{a}}$ & $0.46^{\mathrm{b}}$ & $1.44^{\mathrm{a}}$ & $107.10^{\mathrm{c}}$ & $104.74^{\mathrm{c}}$ & $0.79^{\mathrm{a}}$ \\
\hline
\end{tabular}

Heat denatures ion-containing proteins causing more free ion released. Precooked samples contained more free iron resulting in a higher oxidation rate [36]. The higher oxidation rate in acid silage extraction is predicted caused by protein denaturation.

Saponification Value. The high number of saponification value indicates that the oil has a lower molecular weight of fatty acid than fish oil with low-saponification value [37]. However, it can not be used in the identification process of tuna oil [6].
Iodine Value. According to Chantachum et al [6], the double bonds of the fatty acids are oxidized due to the use of the temperature at the time of cooking prior to being extracted. This is supposedly the cause of the high iodine number in wet rendering extraction method (Table 2)

Thio Barbituric Acid (TBA). According to Tokur et al. [38], the acceptable TBA value is less than $2 \mathrm{mg}$ of malonaldehyde / $\mathrm{kg}$ of oil. Based on the value of TBA obtained in this study, all fish oil from various methods of extraction and from various types of raw materials is edible oil.

TABLE III

FATTY ACID PROFILE OF FISH OIL FROM VARIOUS EXTRACTION METHOD

\begin{tabular}{|c|c|c|c|c|c|c|c|c|c|c|c|c|c|c|c|}
\hline \multirow{2}{*}{$\begin{array}{l}\text { Extraction } \\
\text { Method }\end{array}$} & \multicolumn{15}{|c|}{ Saturated Fatty Acid (SFA) } \\
\hline & C6:0 & $\mathrm{C} 8: 0$ & C10:0 & $\mathrm{C} 12: 0$ & $\mathrm{C} 14: 0$ & $\mathrm{C} 15: 0$ & C16:0 & C18:0 & C20:0 & $\mathrm{C} 22: 0$ & $\mathrm{C} 24: 0$ & & & & $\sum$ SFA \\
\hline $\begin{array}{l}\text { Wet } \\
\text { rendering }\end{array}$ & 0.03 & 0.66 & 0.22 & 0.78 & 2.18 & 2.12 & 10.80 & 7.03 & 1.24 & 1.85 & 1.05 & & & & $27.96^{\mathrm{a}}$ \\
\hline Silage & 0.01 & 0.30 & 0.06 & 0.49 & 2.84 & 2.46 & 12.83 & 9.13 & 1.68 & 4.84 & 3.18 & & & & $37.82^{\mathrm{c}}$ \\
\hline $\begin{array}{l}\text { Solvent } \\
\text { Extraction }\end{array}$ & 0.01 & 0.30 & 0.01 & 0.42 & 3.34 & 3.21 & 10.35 & 6.26 & 1.39 & 3.34 & 2.08 & & & & $30.61^{\mathrm{b}}$ \\
\hline Extraction & \multicolumn{15}{|c|}{ Monounsaturated Fatty Acid (MUFA) } \\
\hline Method & C12:1 & $\mathrm{C} 14: 1 \mathrm{n} 5$ & $\mathrm{C} 16: 1 \mathrm{n} 7$ & C18:1n9 & C20:1n9 & & & & & & & & & & $\sum$ MUFA \\
\hline $\begin{array}{l}\text { Wet } \\
\text { rendering }\end{array}$ & 1.25 & 0.08 & 5.79 & 20.45 & 0.14 & & & & & & & & & & $27.71^{b}$ \\
\hline Silage & 3.23 & 1.08 & 6.37 & 18.57 & 0.10 & & & & & & & & & & $29.41^{\mathrm{c}}$ \\
\hline $\begin{array}{l}\text { Solvent } \\
\text { Extraction }\end{array}$ & 2.43 & 2.08 & 4.58 & 15.72 & 0.08 & & & & & & & & & & $24.89^{\mathrm{a}}$ \\
\hline Extraction & \multicolumn{15}{|c|}{ Polyunsaturated Fatty Acid (PUFA) } \\
\hline Method & $\mathrm{C} 18: 2 \mathrm{n} 6$ & $\mathrm{C} 18: 3 \mathrm{n} 3$ & $\mathrm{C} 18: 3 \mathrm{n} 6$ & $\mathrm{C} 18: 4 \mathrm{n} 3$ & $\mathrm{C} 20: 3 \mathrm{n} 3$ & $\mathrm{C} 20: 3 \mathrm{n} 6$ & $\mathrm{C} 20: 4 \mathrm{n} 6$ & $\mathrm{C} 20: 5 \mathrm{n} 3$ & $\mathrm{C} 22: 5 \mathrm{n} 6$ & $\mathrm{C} 22: 5 \mathrm{n} 3$ & $\mathrm{C} 22: 6 \mathrm{n} 3$ & ALA & EPA & DHA & $\sum$ PUFA \\
\hline $\begin{array}{l}\text { Wet } \\
\text { rendering }\end{array}$ & 5.16 & 3.16 & 3.19 & 7.13 & 2.93 & 1.25 & 1.55 & 6.12 & 3.30 & 1.90 & 8.65 & 3.16 & 6.12 & 8.65 & $44.34^{b}$ \\
\hline Silage & 0.22 & 0.17 & 2.95 & 5.32 & 1.10 & 2.18 & 1.27 & 5.21 & 5.53 & 3.27 & 5.55 & 0.17 & 5.21 & 5.55 & $32.77^{\mathrm{a}}$ \\
\hline $\begin{array}{l}\text { Solvent } \\
\text { Extraction }\end{array}$ & 6.36 & 2.10 & 2.53 & 6.30 & 2.25 & 2.23 & 2.39 & 3.28 & 4.21 & 6.40 & 6.44 & 2.10 & 3.28 & 6.44 & $44.49^{b}$ \\
\hline
\end{tabular}

$\sum$ SFA = sum of Saturated Fatty Acid; $\sum$ MUFA= sum of Monounsaturated Fatty Acid; $\sum$ PUFA= sum of Polyunsaturated Fatty Acid

* Mean indicated by different letters in the same column differ according to the DNMRT at $5 \%$ probability

${ }^{\mathrm{a}-\mathrm{c}}$ Different superscripts indicate a significant difference at $P<0.05$ for DNMRT (Duncan's New Multiple Range Test)

\section{Effect of Extraction Method on Fatty Acid Profile of Fish Oil}

The method of oil extraction has a significant different effect on the content of these three types of fatty acids. It is seen that the extraction with the wet rendering and solvent extraction methods is better in extracting PUFA than the acid silage method. However, the wet rendering method works best in extracting DHA and EPA compared to the other two methods (Table 3 ). The presence of this variation is consistent with earlier studies which suggest that this variation is due to the variation of polar and non-polar fats in the fish portion $[39,40]$ and the variation in chain length and saturation level [40] and whether the extraction using solvent or not. Saturated Fatty Acid (SFA) is a fatty acid that does not have a double bond. Monounsaturated Fatty Acid (MUFA) having a single double bond, Polyunsaturated Fatty Acid (PUFA) is a fatty acid having double bonds of more than one. The third is a group of fatty acids based on the double bond. The method of oil extraction has a different effect on the content of these three types of fatty acids.

In contrast to the extraction method of fish oil derived from the skin it is seen that extraction with silage method is better in extracting PUFA especially EPA, wet rendering method is better in extracting DHA (Figure 3). The interaction between this extraction method of the fish oil portion is in line with previous studies which suggest the variation of polar and non-polar fats in the fish portion 
$[39,40]$ the variation in chain length and saturation level [40] and whether the extraction using a solvent or not .

\section{CONCLUSION}

It can be concluded that extraction method has an effect to physicochemical properties and fatty acid profile of fish oil. The wet rendering extraction method is the most effective and most potential extraction method to be applied because it produces the highest yield $(12.80 \%)$ compared to the acid silage process $(6.16 \%)$ and solvent extraction method (8.49\%). PUFA produced from wet rendering $44.34 \%$, statistically not different with solvent extraction method (44.89\%), but it higher than acid silage process $(32.77 \%)$.

\section{REFERENCES}

[1] Taylor, K.D.A., A. Himonides, and C. Alasalver. 2007. Increased processed flesh yield by recovery from marine by-products. inL Maximazing the Value of Marine By-Products, ed. Shahidi. CRC Presss, Boca Raton, FL, pp.91-106

[2] Junker B, M Lester, T Brix, D Wong dan JA Nuechterlein. 2006. Next generation, pilot-scale continuous sterilization system for fermentation media. Bioproc Biosys Eng. 28: 351 -378.

[3] Chow CK. 2000. Fatty Acids in Foods and their Health Implications (2nd ed). New York (US): Marcel Dekker.

[4] Sybille Merkle, Editha Giese, Sascha Rohn , Horst Karl, Ines Lehmann, Andreas Wohltmann, Jan Fritsche. 2017. Impact of fish species and processing technology on minor fish oil components Food Control 73: 1379-1387]..

[5] Gogus, U., Smith, C. 2010. n-3 Omega fatty acids: a review of current knowledge. International Journal of Food Science \& Technology, 45(3), 417-436.

[6] Chantachum S, Benjakul S, Sriwirat, N. 2000. Separation and quality of fish oil from precooked and non-precooked tuna heads. Food Chem 69(3): 289-294. DOI:10.1016/S0308-8146(99)00266-6.

[7] Aidos I, van-der-Padt A, Boom RM, Luten JB. 2002. Seasonal changes in crude and lipid composition of herring fillets, by-products and respective produced oils. J Agric Food Chem. 50 (16): 45894599. DOI: $10.1021 / \mathrm{jf} 0115995$.

[8] Aryee, A.N.A., B. K. Simpson. 2009. Comparative studies on the yield and quality of solvent-extracted oil from salmon skin. Journal of Food Engineering 92 (3): 353-358.

[9] Zuta CP, Simpson, Ben K, Chan HM, Phillips L. 2003. Concentrating PUFA from mackerel processing waste. $J$ Am Oil Chem Soc. 80 (9) : 933-936 DOI: 10.1007/s11746-003 -0799-5.

[10] Fiori L, Solana M, Taosi P, Manfrini M, Strim C, Guella G. 2012. Lipid profiles of oil trout (Oncorhyncus mykiss) heads, spines, and viscera: Trout by-products as possible source of omega-3 lipids?. Food Chem 134(2): 1088-1095.

[11] Crexi VT, Maurucio LM, Leonor AdZS, Luiz AAP. 2010. Production and refinement of oil form carp (Cyprinus carpio) viscera. Food Chem: 119 (3). 945-950..

[12] Thammapat P, Raviyan P, Siriamornpun S. 2010. Proximate and fatty acids composition of the muscles and viscera of Asian catfish (Pangasius bocourti). Food Chem 122(1): 223-227.

[13] FAO. 1995. Quality and quality changes in fresh fish. Chemical composition. Available from: http://www.fao.org/docrep/v7180e/ V7180E05.htm

[14] Yee, TH. 2007. Influence of extraction temperature and time on yield and quality of oil recovered from Tilapia (Oreochromis niloticus) by product [Thesis]. Malaysia: University Sains Malaysia.

[15] Linder M, Fanni J, Parmentier M.. 2005. Proteolytic extraction of salmon oil and PUFA concentration by lipases. Mar Biotechnol (NY) 7: 70-76.

[16] Letisse, M., Rozieres, M., Hiol, A., Sergent, M., Comeau, L., 2006. Enrichment of EPA and DHA from sardine by supercritical fluid extraction without organic modifier. I. Optimization of extraction conditions. Journal of Supercritical Fluids 38 (1), 27-36.

[17] Rubio-Rodríguez, N., Sara M. de Diego, Sagrario Beltrán $\Uparrow$, Isabel Jaime, María Teresa Sanz, Jordi Rovira. 2012. Supercritical fluid extraction of fish oil from fish by-products: A comparison with other extraction methods Journal of Food Engineering 109: 238-248
[18] Arruda LF, Borghesi R, Portz L, Cyrino JEP, Oetterer M. 2009. Fish silage in black bass (Micropterus salmoides) feed as an alternative to fish meal. Braz Archives Biol Technol 52:126-6.

[19] Cacace, J.E. \& Mazza, G.. 2003. Mass transfer process during extraction of phenolic compounds 446 from milled berries. Journal of Food Engineering, 59(4), 379-389.)

[20] Shanmugam, K and A A. Donaldson. 2015. Extraction of EPA/DHA from 18/12EE Fish Oil Using $\mathrm{AgNO}_{3}(\mathrm{aq})$ : Composition, Yield, and Effects of Solvent Addition on Interfacial Tension and Flow Pattern in Mini-Fluidic Systems.-Ind. Eng. Chem. Res., 2015, 54 (33), pp 8295-8301.

[21] Suseno, S.H., Nurjanah, Yoshiara, Saraswati. 2015. Determination of extraction temperature and period of fish oil from tilapia (oreochromis niloticus) by product using wet rendering method. KnE life sciences|Int. symposium on aquatic product processing (isapprosh) $2013 \quad$ pages: 125-135. doi http://dx.doi.org/10.18502/kls.v1i0.96]

[22] Abdillah, M.H.. 2008. Pemurnian Minyak Dari Limbah Pengolahan Ikan. Skripsi. Fakultas Teknologi Bogor.

[23] Steel, R. G. D., \& Torrie, J. H. (1980). Principles and procedure of statistics (2nd ed.). New York: McGraw \pm Hill.

[24] AOCS Official Method Ca 5a-40 (1997) Free Fatty Acids. American Oil Chemists Society, Champaign, Illinois, USA.

[25] AOCS. 1993. Official Methods and Recommended Practices of the American Oil Chemists' Society, AOC Press. Washington, DC]

[26] AOCS Official Method Cd 8-53 (2003) Peroxides in fats and oils. American Oil Chemists Society, Champaign, Illinois, USA.

[27] Singh,P.R., D.S. Gupta, K.S. Bajpai. Experimental Organic Chemistry, vol. 2, Tata McGraw-Hill (1981), p. 301

[28] Sudarmadji, S. 1997. Prosedur Analisis Untuk Bahan Makanan dan Pertanian. Edisi ke tiga, Liberty, Yokyakarta.

[29] O'Fallon, J. V., Busboom, J. R., Nelson, M. L., \& Gaskins, C. T. .2007. A direct method for fatty acid methyl ester synthesis: application to wet meat tissues, oils, and feedstuffs. Journal of Animal Science, 85, 1511-1521

[30] Nazir, N.. 2011. Pengembangan proses pembuatan biodiesel Jarak pagar melalui transesterifikasi insitu, katalis heterogen kalsium oksida,detoksifikasi dan uji toksisitas bungkil Jarak hasil detoksifikasi. [PhD Dissertation]. Bogor. Institut Pertanian Bogor.

[31] Johnson RB, Barnett HJ (2003) Determination of fat content in fish feed by supercritical fluid extraction and subsequent lipid classification of extract by thin layer chromatography-flame ionization detection. Aquaculture, 216: 263-282.

[32] Ghaly AE, Ramakrishnan VV, Brooks MS, Dave D (2013) Fish processing wastes as a potential source of proteins, amino acids and oils: A critical review. Journal of Microbial \& Biochemical Technology 5: 107-129.

[33] Nawar, W. W. .1996. Lipids. In O. R. Fennema, Food Chemistry (pp. 225 \pm 319 ). New York: Marcel Dekker.

[34] Gunawan, M.T dan A. Rahayu. 2003. Analisis Pangan: Penentuan Angka Peroksida dan Asam Lemak Bebas pada Minyak Kedelai dengan Variasi Menggoreng. JSKA Vol VI. No 3.

[35] Ekwu, F.C., and A. Nwagu. 2004. Effect of processing on the quality of cashew nut oils. J. Sci. Agric. Food Tech. Environ., 4: pp. 105110

[36] Arruda, L.F, R. Borghesi, M. Oetterer. 2007.Use of fish waste as silage - a review. . Braz. Arch. Biol. Technol. vol.50 no.5:879-886.

[37] Low, L. K.,\& Ng, C. S. 1987. Determination of saponification value. In H. Hasegawa, Laboratory manual on analytical methods and procedures.

[38] Tokur, B., K, Korkmaz and D. Ayas. 2006. Comparison of two thiobarbituric acid (TBA) method for monitoring lipid oxidation in fish. Journal of Fisheries and Aquatic Sciences 23 (3): 331-334

[39] Aursand, M., Bleivik, B., Rainuzzo, J.R., Jørgensen, L., Mohr, V., 1994. Lipid distribution and composition of commercially farmed Atlantic salmon (Salmo salar). J. Sci. Food Agric. 64, 239-248.

[40] Jobling, M., Larsen, A.V., Andreassen, B., Sigholt, T., Olsen, R.L., 2002. Influence of a dietary shift on temporal changes in fat deposition and fatty acid composition of Atlantic salmon post-smolt during the early phase of seawater rearing. Aquaculture Research 33 (11), 875-889. 